
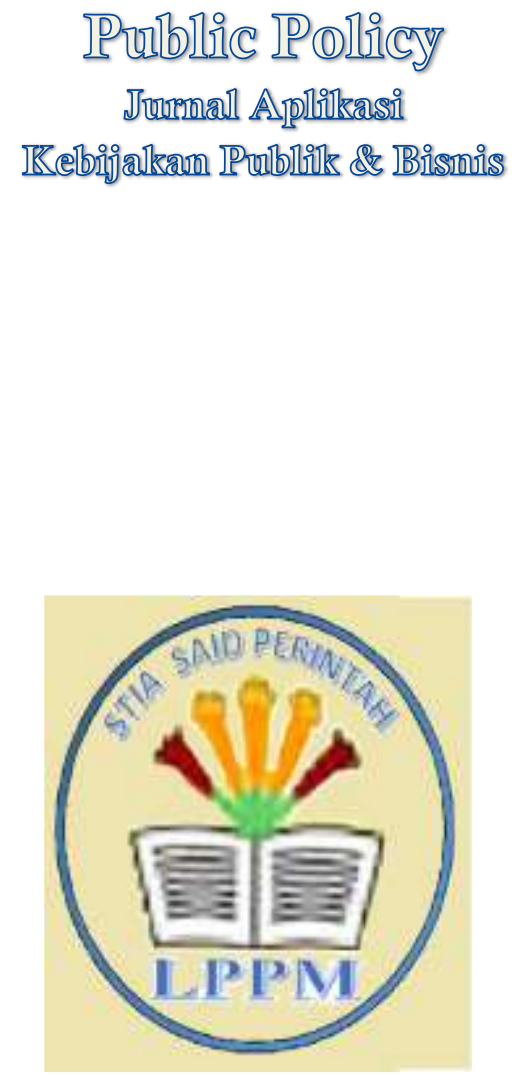

LPPM STIA Said Perintah

Volume 1, No. 2, September 2020

https://stia-saidperintah.e-journal.id/ppj

\section{Determinan Penyaluran Kredit UMKM PT. Bank Maluku Malut}

\author{
Samie Lambert Jacobs ${ }^{1}$ \\ Maximiliane L. C. Hukom ${ }^{2}$ \\ STIEM Rutu Nusa Ambon ${ }^{1}$ \\ Universitas Kristen Indoneia Maluku² \\ nanehukom@gmail.com
}

\begin{abstract}
This study aims to analyze the influence Capital Adequacy Ratio (CAR), Non Performing Loan (NPL), Return on Assets (ROA) against lending UMKM banking on PT Maluku Regional Development Bank Maluku, Maluku Utara. The object of this research is a banking company BPDM, Maluku Utara period 2015 - 2019. Hypothesis testing is tested empirically using Multiple Linear Regression and Classical Assumption Test. Based on the analysis that has been done, the results show that the ratio is partial CAR, NPL and ROA has a significant positive effect on lending UMKM at Maluku Regional Development Bank Maluku, Maluku Utara period 2015 - 2019. This is evidenced by a significant level CAR, NPL and ROA that is smaller than 0,05 so that from the results of processing SPSS obtained the magnitude of $R$ sguare $\left(r^{2}\right)$ is 0.991 . This figure means that the effect of the three independent variables used in this study, jointly (simultaneously) has an effect on lending UMKM at Maluku Regional Development Bank Maluku, Maluku Utara is 99,1\%. The remaining $08.0 \%$ was influenced by other factors. In other words, variable CAR, NPL and ROA is $99.1 \%$, while $09.0 \%$ is caused by other variables outside this model.
\end{abstract}

Keywords : CAR, NPL, ROA, UMKM Credit

\title{
Pendahuluan
}

Pembangunan ekonomi suatu negara bergantung pada perkembangan sektor perbankan karena perbankanlah yang berperan dalam pembiayaan pembangunan ekonomi. Kegiatan utama suatu bank yaitu menghimpun dana masyarakat dan menyalurkan kembali pada masyarakat untuk meningkatkan kesejahteraan rakyat. Dana yang dihimpun dari masyarakat menjadi sumber dana terbesar untuk melakukan aktivitas kredit.

Kredit merupakan alokasi dana yang terbesar bagi bank memberi 
keuntungan yang besar bagi bank. Namun meskipun demikian, risiko yang dihadapi bank dalam penyaluran kredit tersebut juga besar. Oleh karena itu bank harus hati-hati dalam menyalurkan kreditnya. Penyaluran kredit sebagai bentuk usaha bank mutlak dilakukan karena fungsi bank itu sendiri merupakan lembaga intermediasi yang mempertemukan kepentingan antara pihak-pihak yang kelebihan dana (unit surplus) dengan pihak yang kekurangan dana (unit defisit).

Bank dalam menyalurkan kreditnya dipengaruhi oleh faktor internal dan eksternal. Faktor internal bank seperti kemampuan bank dalam menghimpun dana masyarakat dan tingkat kesehatan bank, sedangkan faktor eksternal bank dipengaruhi oleh kondisi perekonomian, peraturan pemerintah, situasi polotik (Pratama, 2010).

Perkembangan potensi Usaha Mikro, Kecil, dan Menengah (UMKM) di Indonesia tidak terlepas dari dukungan perbankan dalam penyaluran kredit kepada UMKM. Setiap tahun kredit kepada UMKM mengalami pertumbuhan dan secara umum pertumbuhannya lebih tinggi dibanding total kredit perbankan. Kredit UMKM adalah kredit kepada debitur usaha mikro, kecil dan menengah yang memenuhi definisi dan kriteria usaha mikro, kecil dan menengah sebagaimana diatur dalam UU No. 20 Tahun 2008 Tentang UMKM.

Kredit UMKM merupakan salah satu kebijakan pemerintah dalam upaya meningkatkan perekonomian negara yang dijalankan melalui bank. Program ini memberikan kemudahan bagi masyarakat dalam memperoleh modal untuk membangun UMKM. UMKM ini merupakan kelompok usaha yang memiliki keunggulan dalam sisi penyerapan tenaga kerjanya yang banyak, sehingga dapat membantu proses pemerataan yang merupakan bagian dari pembangunan ekonomi negara (Nasution, 2013).

Pemerintah Indonesia sendiri telah melakukan berbagai usaha dalam memajukan perekonomian Indonesia, salah satunya adalah dengan cara meningkatkan kinerja UMKM. Seperti dalam instruksi Presiden Republik Indonesia Nomor 6 Tahun 2007 tentang kebijakan percepatan pengembangan sektor riil dan pemberdayaan usaha mikro, kecil dan menengah. Hal tersebut disebabkan sejalan dengan perkembangan jumlah UMKM di Indonesia yang terus meningkat 
dari tahun ketahun, sehingga pemerintah melihat adanya kesempatan dan potensi yang baik dalam memaksimalkan sektor UMKM ini. Hal tersebut sejalan dengan perkembangan jumlah UMKM di Indonesia yang terus meningkat dari tahun ketahun, sehingga pemerintah melihat adanya kesempatan dan potensi yang baik dalam memaksimalkan sektor UMKM ini.

Penyaluran UMKM di provinsi Maluku mengalami peningkatan sebesar 21,30\% atau sebesar 547,79 meliar, menjadi 3,12 triliun penyaluran kredit ini berada pada posisi desember 2017. Penyaluran kredit UMKM masi dinominasi kepada usaha kecil yang mencapai Rp. 1,26 triliun rupiah atau sebesar 40,26\% dari total kredit UMKM. Dengan perkembangan ini menunjukan bahwa pangsa pasar pembiyaan di Profinsi Maluku cukup potensial sehingga diharapkan akan semakin mempercepat peningkatan pertumbuhan ekonomi daerah dan peningkatan ekonomi masyarakat yang lebih baik.

Berdasarkan tabel di bawah ini dapat diketahui bahwa jumlah penyaluran UMKM dari tahun 2015-2019 mengalami peningkatan fulkutuasi dengan kencendrungan menurun.

Rasio Penyaluran Kredit UMKM PT. Bank Maluku Malut

\begin{tabular}{|c|c|c|c|c|c|}
\hline Rasio & $\mathbf{2 0 1 5}$ & $\mathbf{2 0 1 6}$ & $\mathbf{2 0 1 7}$ & $\mathbf{2 0 1 8}$ & $\mathbf{2 0 1 9}$ \\
\hline CAR & 6.731 .909 & 6.005 .907 & 5.290 .774 & 4.605 .882 & 4.231 .779 \\
\hline NPL & 4.748 .083 & 4.217 .195 & 3.941 .985 & 3.359 .377 & 3.239 .617 \\
\hline ROA & 8.392 .534 & 7.279 .451 & 6.735 .072 & 6.341 .960 & 6.014 .362 \\
\hline UMKM & 314.078 & 314.847 & 318.490 & 223.333 & 250.197 \\
\hline
\end{tabular}

Jumlah penyaluran kredit UMKM yang di salurkan kepada debitur selama 5 tahun, mengalami peningkatan tahun 2015 penyaluran kredit sebesar Rp. 314.078 juta, dengan rasio CAR 18.66\%, tahun 2016 tingkat penyaluran kredit sebesar Rp. 314.847 juta rupiah dengan rasio CAR $19.50 \%$, demikian dengan tingkat penyaluran kredit UMKM pada tahun 2017, 2018 dan 2019 dengan masing-masing rasio keuangan $\mathrm{CAR}, \mathrm{NPL}$, ROA juga mengalami peningkatan fulktuasi dengan kecendrungan menurun seperti tabel di atas.

Jumlah volume kredit yang disalurkan oleh bank kepada debitur memiliki beberapa faktor internal dan faktor eksternal. Dari sisi internal bank sangat 
dipengaruhi oleh kemampuan bank dalam menghimpun dana masyarakat dan penentuan tingkat suku bunga. Faktor-faktor yang mempengaruhi volume penyaluran kredit bank adalah Dana Pihak Ketiga (DPK), Non-Performing Loan (NPL), suku bunga Sertifikat Bank Indonesia (SBI) dan suku bunga KUR. Volume penyaluran kredit juga dipengaruhi oleh faktor-faktor eksternal bank seperti kondisi ekonomi, peraturan pemerintah dan lain-lain.

Menurut (Triasdini, 2010) terdapat pengaruh CAR (Capital Adequacy Ratio), NPL (Non-Performing Loan) dan ROA (Return on Assets) terhadap kredit modal kerja. Sedangkan menurut Wardahni (2011) terdapat pengaruh dari spread tingkat suku bunga bank, CAR dan NPL terhadap penyaluran kredit UMKM. Dan menurut hasil penelitian dari (Pratama, 2010) terdapat pengaruh dari DPK (Dana Pihak Ketiga), CAR (Capital Adequacy Ratio), NPL (Non-Performing Loan.

\section{Kerangka Teoritis dan Pengembangan Hipotesa Penelitian}

Pengertian kredit UMKM menurut Bank Indonesia adalah semua penyediaan uang atau tagihan yang dapat dipersamakan dengan itu dalam rupiah dan valuta asing, berdasarkan persetujuan atau kesepakatan pinjam meminjam antara bank pelapor dengan bank dan pihak bukan bank yang memenuhi kriteria usaha sesuai dengan Undang-Undang tentang UMKM yang berlaku.

Menurut undang-undang Republik Indonesia nomor 10 tahun 1998 kredit adalah suatu kesepakatan pinjam-meminjam antara pihak bank dengan pihak yang meminjam yang diwajibkan melunasi utangnya pada jangka waktu tertentu ditambah bunga peminjaman sesuai kesepakatan. Adapun menurut (Nasution, 2013) kredit adalah kemampuan dalam mengadakan suatu transaksi pembelian dengan janji pembayaran akan dilakukan pada jangka waktu yang disepakati kedua belah pihak.

\section{Penggolongan Kredit}

Penggolongan kredit dibagi menajadi lima golongan, yaitu berdasarkan jangka waktu (maturity), barang jaminan (collatera), segmen usaha, tujuan kredit, dan pengunaan kredit.

1. Berdasarkan jangka waktu (maturity) dibedakan menjadi: 
a. Kredit jangka pendek (short-term loan) adalah kredit yang jangka waktu pengembaliannya kurang dari satu tahun.

b. Kredit jangka menengah (medium-term loan) adalah kredit yang jangka waktu pengembaliannya 1-3 tahun.

c. Kredit jangka panjang (long-term loan) adalah kredit yang jangka waktu pengembaliannya lebih dari tiga tahun.

2. Berdasarkan barang jaminan (collatera) dibedakan menjadi

a. Kredit dengan jaminan (secured loan)

b. Kredit tanpa jaminan (un secured loan)

3. Berdasarkan segmen usaha dibedakan menjadi :
a. Perdagangan
b. Otomotif
C. Farmasi
d. Teksitil
e. Makanan
f. Konstruksi, dan lain-lain

4. Berdasarkan tujuan kredit dibedakan menjadi :

a. Kredit komersil (commercial loan), adalah kredit yang digunakan untuk memperlancar kegiatan usaha nasabah dibidang perdagangan.

b. Kredit konsumtif (consumer loan) adalah kredit yang diberikan oleh bank guna memenuhi kebutuhan debitur yang bersifat konsumtif.

c. Kredit produktif adalah kredit yang diberikan oleh pihak bank guna memenuhi kebutuhan debitur dalam membiayai kebutuhan modal kerjanya.

5. 5. Berdasarkan penggunaan kredit dibedakan menjadi;

a. Kredit modal kerja, adalah kredit yang diberikan bank kepada debitur guna menambah modal kerja. Modal kerja tersebut meliputi berbagai aspek, seperti untuk tujuan komersil, industry, kontraktor bangunan dan lain-lain

b. Kredit Investasi, adalah kredit yang diberikan bank kepada perusahaan untuk berinvestasi dengan membeli barang-barang modal. Kredit investasi ini biasanya berupa kredit jangka menengah atau panjang. 


\section{Non-Performing Loan (NPL)}

Semakin rendah NPL maka akan semakin besar kemungkinan kredit yang akan disalurkan. NPL merupakan salah satu faktor yang dapat menghambat penyaluran kredit. NPL menunjukkan tingkat kualitas aset sebuah bank (Kusnandar, 2012). Semakin tinggi rasio NPL bank, maka penyaluran kredit akan terhambat (Panggalih, 2015). Menurut Peraturan Bank Indonesia Nomor 6/10/PBI/2004 tentang Sistem Penilaian Tingkat Kesehatan Bank Umum, apabila rasio NPL di atas 5\%, maka bank tersebut terindikasi tidak sehat. Menurut ketentuan Bank Indonesia, kredit bermasalah digolongkan berdasarkan kolektibilitasnya yaitu Kurang Lancar (KL), Diragukan (D), dan Macet (M).

\section{Pengaruh Antara CAR dengan Penyaluran Kredit UMKM}

CAR merupakan rasio permodalan yang menunjukkan kemampuan bank dalam menyediakan dana untuk keperluan pengembangan usaha dan penanggungan risikorisiko yang mungkin terjadi. Semakin tinggi persentase CAR suatu bank, maka semakin baik kinerjanya (Huda, 2014). Tingginya CAR suatu bank menandakan bahwa modal yang dimiliki bank tersebut juga tinggi, sehingga hal tersebut berpengaruh terhadap salah satu kegiatan operasionalnya yaitu menyalurkan kredit UMKM (Mahendra, 2011). Selain itu, kecukupan modal yang tinggi dan memadai akan meningkatkan volume kredit perbankan (Siregar, 2009). Jumlah penyaluran kredit yang disalurkan oleh perbankan dipengaruhi oleh rasio kecukupan modal, yaitu CAR. Menurut (Huda, 2014), dan (Mahendra, 2011) CAR secara parsial berpengaruh positif signifikan terhadap penyaluran Kredit Usaha Rakyat (KUR). Berdasarkan ulasan ini maka hipotesa yang diajukan untuk diuji dalan kajian ini adalah;

$\mathrm{H}_{1}$; Capital Adequacy Ratio (CAR) berpengaruh positif terhadap penyaluran kredit Kredit UMKM di Bank Pembangunan Daerah Maluku dan Maluku Utara.

\section{Pengaruh Antara NPL Dengan Penyaluran Kredit UMKM}

NPL merupakan perbandingan antara kredit dengan kualitas lancer, diragukan dan macet dengan total kredit. Menurut (Pratama, 2010) bahwa peningkatan atau penurunan NPL mempengaruhi penyaluran kredit secara signifikan dan negative. Semakin tinggi NPL maka akan mendorong penururnan jumlah kredit, dengan begitu pula sebaliknya. Hal sama juga diteliti oleh (Meyddinawathi, 2007) yaitu setiap 
kenaikan jumlah NPL dari total kredit modal kerja maupun kredit investasi kepada sektor UMKM, maka akan menyebabkan penurunan jumlah penawaran kedua jenis kredit tersebut terhadap sektor UMKM. Oleh karena itu bank dituntut untuk selalu menjaga kreditnya agar terhindar dari kredit macet. Tingkat wajar NPL adalah sekitar 3-5\%. (Fitria, 2012). Berdasarkan ulasan ini maka hipotesa yang diajukan untuk diuji dalan kajian ini adalah;

$\mathrm{H}_{2}$; Non-Performing Loan (NPL) berpengaruh positif terhadap penyaluran kredit Kredit UMKM di Bank Pembangunan Daerah Maluku dan Maluku Utara.

\section{Pengaruh Antara ROA dengan Penyaluran Kredit UMKM}

ROA adalah rasio untuk mengukur kemampuan manajemen bank dalam memperoleh keuntungan secara keseluruhan. Menuut (Annisa Nurlestari, 2015). Hasil penelitian menunjukkan bahwa variabel ROA memiliki pengaruh yang paling besar terhadap jumlah penyaluran kredit UMKM perbankan. Semakin tinggi Return on Assets (ROA) yang didapatkan oleh bank maka akan semakin tinggi pula jumlah kredit UMKM yang disalurkan oleh bank. Oleh karena itu, bank perlu mengatur seluruh alokasi asetnya agar jumlah pengembalian atas aset diperoleh secara maksimal. Hal tersebut memerlukan manajemen dan kinerja bank yang baik. Sehingga dana yang didapat dari pengembalian atas aset tersebut dapat disalurkan kepada kredit UMKM yang akan disalurkan oleh bank.

Menurut (Triasdini, 2010) ROA berpengaruh signifikan terhadap penyaluran Kredit Modal Kerja yang bisa disebut juga dengan KUR. Dalam menyalurkan kreditnya bank bergantung pada alokasi tingkat ROA yang diperoleh tahun lalu. Hal tersebut dikarenakan semakin tinggi nilai ROA pada tahun sebelumnya maka semakin stabil kualitas aktiva dan semakin baik manajemen labanya, sehingga memungkinkan bank untuk menyalurkan kredit lebih banyak ditahun berikutnya.

Selain itu menurut (Kusnandar, 2012) bank dengan tingkat pengembalian yang tinggi atas aset, memiliki kecenderungan memperoleh laba lebih besar sehingga memiliki kemampuan lebih besar untuk meningkatkan kredit UMKM, karena bank dalam posisi memiliki tingkat kinerja yang cukup baik. Menurut (Trimulyanti, 2013) adalah tingkat keuntungan yang didapatkan oleh bank akan terkait dengan jumlah dana yang dihimpun dan disalurkan, maka rentabilitas yang dimiliki oleh bank akan 
meningkat dan kredit yang disalurkan juga akan meningkat. Menurut (Triasdini, 2010) menyatakan bahwa penganggaran volume kredit akan meningkat tergantung besarnya posisi LDR, Net Open Position, dan ROA. Berdasarkan ulasan ini maka hipotesa yang diajukan untuk diuji dalan kajian ini adalah;

$\mathrm{H}_{3}$; Return on Assets (ROA) berpengaruh positif terhadap penyaluran kredit Kredit UMKM di Bank Pembangunan Daerah Maluku dan Maluku Utara.

$\mathrm{H}_{4}$; Capital Adequacy Ratio (CAR), Non-Performing Loan (NPL) dan Return on Assets (ROA) berpengaruh positif secara simultan terhadap penyaluran kredit Kredit UMKM di Bank Pembangunan Daerah Maluku dan Maluku Utara.

\section{Metode Penelitian}

Penelitian ini bertujuan untuk mengukur pengaruh antara variabel independen CAR (Capital Adequacy Ratio), NPL (Non-Performing Loan), dan ROA (Return on Assets) pada penyalur kredit UMKM. Hasil penelitian tersebut diharapkan dapat memberikan fakta dan temuan yang spesifik yang berkontribusi pada pengembangan keilmuan, khususnya yang terkait dengan teori CAR, NPL, ROA serta kredit UMKM. Jenis data yang digunakan dalam penelitian ini adalah data kuantitatif sedangkan sumber data yang digunakan adalah data sekunder yang bersumber dari Bank Maluku Malut, Badan Pusat Statistik Provinsi Maluku.

Metode yang digunakan dalam penelitian ini adalah metode analisis regresi linier berganda. Analisis regresi linier berganda digunakan untuk memprediksi besar variabel tergantung (dependent variabel) menggunakan data dari dua atau lebih variabel bebas (independent variabe) yang sudah diketahui besarnya (Ghozali, 2011). Sebelum melakukan analisis regresi, dilakukan pengujian asumsi klasik (uji multikolonieritas, uji autokorelasi dan uji heterokedastisitas) terlebih dahulu agar memenuhi syarat BLUE (Best Linear Unbiased Estimator). Model analisis regresi linier berganda (Multiple Regression Analysis) dalam penelitian ini adalah;

$Y=a+\beta_{1} X_{1}+\beta_{2} X_{2}+\beta_{3} X_{3}+\varepsilon$

Dimana;

$\mathrm{Y}=$ Penyalur Kredit UMKM

$\mathrm{X}_{1}=\mathrm{CAR}$ (Capital Adequacy Ratio) 


$$
\begin{aligned}
& X_{2}=\text { NPL (Non-Performing Loan) } \\
& X_{3}=\text { ROA (Return on Assets) } \\
& \beta_{0}=\text { Konstanta } \\
& \beta_{1}, \beta_{2}, \beta_{3}=\text { Koefisien Regresi } \\
& t \quad=\text { Tahun } \\
& \varepsilon=\text { Error }
\end{aligned}
$$

\section{Pembahasan Hasil Penelitian}

Hasil analisis data di atas pada kolom Kolmogorov-Smirnov dapat diketahui bahwa nilai signifikansi untuk setiap rasio sebesar 0,05; untuk rasio CAR nilai signifikan sebesar 0,200; rasio NPL 0.200 dan untuk rasio ROA sebesar 0.200 serta tingkat penyaluran kredit UMKM sebesar 0,037. Karena signifikansi untuk seluruh variabel lebih besar dari 0,05 maka dapat disimpulkan bahwa data pada variabel $C A R, N P L$, ROA dan UMKM berdistribusi normal.

\section{Hasil Uji Multikolonieritas}

Uji multikolinearitas digunakan untuk mengetahui ada atau tidaknya

\begin{tabular}{|c|c|c|c|c|c|c|c|c|}
\hline \multicolumn{9}{|c|}{ Coefficients $^{a}$} \\
\hline \multirow{2}{*}{\multicolumn{2}{|c|}{ Model }} & \multicolumn{2}{|c|}{$\begin{array}{l}\text { Unstandardized } \\
\text { Coefficients }\end{array}$} & \multirow{2}{*}{$\begin{array}{c}\begin{array}{c}\text { Standardized } \\
\text { Coefficients }\end{array} \\
\text { Beta }\end{array}$} & \multirow[t]{2}{*}{$\mathbf{t}$} & \multirow{2}{*}{ Sig. } & \multicolumn{2}{|c|}{$\begin{array}{l}\text { Collinearity } \\
\text { Statistics }\end{array}$} \\
\hline & & B & Std. Error & & & & Tolerance & VIF \\
\hline \multirow[t]{4}{*}{1} & (Constant) & -1362.255 & 197.403 & & -6.901 & .092 & & \\
\hline & CAR & 33.712 & 2.954 & 2.079 & 11.414 & .056 & .060 & 6.608 \\
\hline & NPL & 133.993 & 27.355 & .624 & 4.898 & .028 & .023 & 8.134 \\
\hline & ROA & 212.858 & 35.411 & .623 & 6.011 & .015 & .016 & 5.379 \\
\hline
\end{tabular}
penyimpangan asumsi klasik multikolinearitas yaitu adanya hubungan linear antar variabel independen dalam model regresi. Prasyarat yang harus terpenuhi dalam model regresi adalah tidak adanya multikolinearitas. Pada pembahasan ini akan dilakukan uji multikolinearitas dengan melihat nilai inflation factor(VIF)

Hasil Uji Multikolonieritas Penyaluran Kredit UMKM 
Berdasarkan hasil pengujian multikolonieritas penyaluran kedit, di ketahui bahwa nilai hitung Tolerance kurang dari 0,1 yang berarti tidak ada korelasi antar variabel independen. Dari hasil output di atas yang ditunjukan dengan nilai VIF, terhadap variabel independen tabel tidak memiliki nilai VIF lebih dari 10. Jadi dapat disimpulkan bahwa tidak ada gejala multikolonieritas antara variabel independen dalam model regresi.

\section{Hasil Uji Heteroskedastisitas}

Uji Hetroskedasitas adalah uji yang menilai apakah ada ketidaksamaan varian dari residual untuk semua pengamatan pada model regresi linier. Uji ini merupakan salah satu dari uji asumsi klasik yang harus dilakukan pada regresi linear. Apabila asumsi heteroskedasitas tidak terpenuhi, maka model regresi dinyatakan tidak valid sebagai alat peramalan

Hasil UJi Heteroskedasitas

\begin{tabular}{|c|c|c|c|c|c|c|}
\hline \multicolumn{7}{|c|}{ Coefficients $^{a}$} \\
\hline \multirow{2}{*}{\multicolumn{2}{|c|}{ Model }} & \multicolumn{2}{|c|}{$\begin{array}{l}\text { Unstandardized } \\
\text { Coefficients }\end{array}$} & \multirow{2}{*}{$\begin{array}{c}\begin{array}{c}\text { Standardized } \\
\text { Coefficients }\end{array} \\
\text { Beta }\end{array}$} & \multirow[t]{2}{*}{$\mathbf{t}$} & \multirow[t]{2}{*}{ Sig. } \\
\hline & & B & Std. Error & & & \\
\hline \multirow[t]{4}{*}{1} & (Constant) & -1362.255 & 197.403 & & -6.901 & .092 \\
\hline & CAR & 33.712 & 2.954 & 2.079 & 11.414 & .056 \\
\hline & NPL & 133.993 & 27.355 & .624 & 4.898 & .128 \\
\hline & ROA & 212.858 & 35.411 & .623 & 6.011 & .105 \\
\hline
\end{tabular}

Uji Glejser dilakukan dengan cara meregresikan antara variabel independen dengan nilai absolut residualnya. Jika nilai signifikansi antara variabel independen dengan absolut residual lebih dari 0,05 maka tidak terjadi masalah heteroskedastisitas. Dari output di atas dapat diketahui bahwa nilai signifikansi ketiga variabel independen lebih dari 0,05. Dengan demikian dapat disimpulkan bahwa tidak terjadi masalah heteroskedastisitas pada model regresi.

\section{Hasil Uji Autokorelasi}

Uji autokorelasi digunakan untuk mengetahui ada atau tidaknya penyimpangan asumsi klasik autokorelasi yaitu korelasi yang terjadi antara residual pada satu 
pengamatan dengan pengamatan lain pada model regresi. Prasyarat yang harus terpenuhi adalah tidak adanya autokorelasi dalam model regresi. Metode pengujian yang sering digunakan adalah dengan uji Durbin-Watson (uji DW) dengan ketentuan sebagai berikut;

1) Jika d lebih kecil dari dL atau lebih besar dari (4-dL) maka hopotesis nol ditolak, yang berarti terdapat autokorelasi.

2) Jika d terletak antara dU dan (4-dU), maka hipotesis nol diterima, yang berarti tidak adaautokorelasi.

3) Jika d terletak antara dL dan dU atau diantara (4-dU) dan (4-dL), maka tidak menghasilkan kesimpulan yang pasti.

Nilai du dan dl dapat diperoleh dari tabel statistik Durbin Watson yang bergantung banyaknya observasi dan banyaknya variabel yang menjelaskan. Sebagai contoh kasus kita mengambil contoh kasus pada uji normalitas pada pembahasan sebelumnya. Pada contoh kasus tersebut setelah dilakukan uji normalitas, multikolinearitas, dan heteroskedastisitas maka selanjutnya dilakukan pengujian autokorelasi.

\section{Hasil Uji Aoutokorelasi}

\begin{tabular}{|l|r|r|r|r|r|}
\hline \multicolumn{7}{|c|}{ Model Summary $^{\mathbf{b}}$} \\
\hline Model & $\mathbf{R}$ & R Square & $\begin{array}{c}\text { Adjusted R } \\
\text { Square }\end{array}$ & $\begin{array}{l}\text { Std. Error of } \\
\text { the Estimate }\end{array}$ & Durbin-Watson \\
\hline 1 & $.999^{\mathrm{a}}$ & .998 & .992 & 4.864 & 1.387 \\
\hline \multicolumn{2}{|l|}{ a. Predictors: (Constant), ROA, NPL, CAR } & & \\
\hline b. Dependent Variabel: UMKM
\end{tabular}

Hasil output di atas didapat nilai DW yang dihasilkan dari model regresi adalah 1,387. Sedangkan dari tabel DW dengan signifikansi 0,05 dan jumlah data $(n)=5$, seta $\mathrm{k}=3$ ( $\mathrm{k}$ adalah jumlah variabel independen) diperoleh nilai dL sebesar 1,046 dan dU sebesar 1,535 . Karena nilai DW $(1,387)$ berada pada daerah antara dL dan dU, maka tidak menghasilkan kesimpulan yang pasti (berada di daerah keragu-raguan).

\section{Uji Regresi Linier Berganda}

Analisis regresi linier berganda adalah alat untuk meramalkan nilai pengaru dua variabel bebas atau lebih terhadap suatu variabel terkait untuk membuktikan ada 
tidaknya ubungan fungsional atau hubungan kausal Antara dua atau lebih variabel bebas $(X)$ terhadap suatu variabel terikait $(Y)$.

\section{Hasil Uji Hipotesis}

Uji hipotesis bertujuan untuk menjawab rumusan masalah yang di kemukakan dalam penelitian ini, apakah ketiga variabel bebas yang digunakan yakni CAR (X1), NPL (X2) dan ROA (X3) secara simultan dan parsial berpengaruh terhadap variabel terikat $Y$ (Penyaluran Kredit UMKM). Dilakukan pengujian melalui uji statistic F dan uji statistic $\mathrm{t}$.

\section{Hasil Uji Signifikansi Simultan (Uji Statistik F)}

Hasil uji F Statistik dapat dijelaskan bahwa nilai F hitung sebesar 35.236 nilai F hitung tersebut jika dibandingakan dengan nilai F tabel sebesar 5. 050 maka dapat dijelaskan bahwa nilai $\mathrm{F}$ hitung lebih besar dari nilai $\mathrm{F}$ tabel yang berarti bahwa dapat disimpulkan bahwa terdapat pengaruh yang signifikan antara variabel bebas $X 1$ (CAR), X2 (NPL) dan X3 (ROA) secara simultan terhadap variabel terikat Y (Penyaluran Kredit UMKM) di Bank Pembangunan daerah Maluku, Malut.

Hasil Uji Signifikansi Simultan (Uji Statistik F)

\begin{tabular}{|c|c|c|c|c|c|c|}
\hline \multicolumn{7}{|c|}{ ANOVA $^{a}$} \\
\hline \multicolumn{2}{|r|}{ Model } & Sum of Squares & df & Mean Square & $\mathbf{F}$ & Sig. \\
\hline \multirow[t]{3}{*}{1} & Regression & 7794991549.014 & 3 & 2598330516.338 & 35.236 & $.123^{b}$ \\
\hline & Residual & 73741136.986 & 1 & 73741136.986 & & \\
\hline & Total & 7868732686.000 & 4 & & & \\
\hline \multicolumn{7}{|c|}{ a. Dependent Variabel: UMKM } \\
\hline
\end{tabular}

Hasil uji F dapat dijelaskan bahwa nilai Sig lebih kecil dari 0,05 $(0,000<0,05)$ sehingga hipotesis yang menyatakan ada pengaruh signifikan variabel independen secara simultan terhadap variabel dependen dapat diterima. Maka dapat disimpulkan bahwa terdapat pengaruh yang signifikan antara CAR (X1), NPL(X2) dan ROA (X3) secara simultan berpengaruh signifikan terhadap Penyaluran Kredit KUMK (Y). di Bank Pembangunan Daerah Maluku, Malut. 


\section{Uji Signifikansi Parameter Individual (Uji Statistik t)}

Hasil uji signifikansi (Uji Statistik t) terhadap ketiga variabel independen, di ketahui variabel independen yakni variabel CAR (X1), NPL (X2) dan Variabel ROA (X3) mempunyai nilai positif sig $<0,05$. Secara parsial $(X 1)$ mempunyai nilai sig sebesar $0.048<0.05$, variabel NPL (X2) mempunyai nilai sig $0.034<0.05$ dan variabel ROA (X3) mempunyai nilai sig $0.037<0.05$ artinya variabel CAR, NPL dan ROA secara parsial berpengaruh secara positif terhadap variabel penyaluran KUMK.

Hasil Uji Signifikansi Parameter Individual (Uji Statistik t)

\begin{tabular}{|c|c|c|c|c|c|c|}
\hline \multicolumn{7}{|c|}{ Coefficients $^{a}$} \\
\hline & \multirow{2}{*}{ Model } & \multicolumn{2}{|c|}{ Unstandardized Coefficients } & \multirow{2}{*}{$\begin{array}{c}\text { Standardized } \\
\text { Coefficients }\end{array}$} & \multirow{2}{*}{$\mathbf{t}$} & \multirow{2}{*}{ Sig. } \\
\hline & & B & Std. Error & & & \\
\hline \multirow[t]{4}{*}{1} & (Constant) & 143117.634 & 63765.422 & & 2.244 & .267 \\
\hline & CAR & .043 & .041 & .992 & 1.059 & .48 \\
\hline & NPL & .284 & .061 & 3.979 & 4.664 & .34 \\
\hline & ROA & .105 & .023 & 2.217 & 4.586 & .37 \\
\hline
\end{tabular}

Hasil temuan dari penelitian ini mendukung beberapa penelitian sebelumnya, yang mengemukakan bahwa kecukupan modal yang tinggi dan memadai akan meningkatkan volume kredit perbankan (Siregar, 2009). Jumlah penyaluran kredit yang disalurkan oleh perbankan dipengaruhi oleh rasio kecukupan modal, yaitu CAR. Menurut (Huda, 2014), (Trimulyanti, 2013), (Triasdini, 2010) CAR secara parsial berpengaruh positif signifikan terhadap penyaluran Kredit Usaha Rakyat (KUR). Menurut Pratama, (2010) bahwa peningkatan atau penurunan NPL mempengaruhi penyaluran kredit secara signifikan dan negative. Semakin tinggi NPL maka akan mendorong penururnan jumlah kredit, dengan begitu pula sebaliknya.

Menurut (Kusnandar, 2012) bank dengan tingkat pengembalian yang tinggi atas aset, memiliki kecenderungan memperoleh laba lebih besar sehingga memiliki kemampuan lebih besar untuk meningkatkan kredit UMKM, karena bank dalam posisi memiliki tingkat kinerja yang cukup baik. Berdasarkan hasil pengujian pada tabel di atas di peoleh persamaan regresi linier berganda sebagai berikut; $Y=14317634+$ $0.43 X_{1}+0.284 X_{2}+0.105 X_{3}$ 
Berdasarkan hasil persamaan regresi linier berganda variabel (X1) CAR (Capital Adequacy Ratio) Rasio kecukupan modal yang menunjukkan kemampuan bank dalan menyediakan dana untuk pengembangan bank melalui penyaluran kredit UMKM berpengaruh positif dengan nilai koefisien sebesar 0.43 ini berarti setiap kenaikan nilai variabel CAR sebesar 1 persen maka nilai variabel CAR akan bertambah sebesar 0.43 dengan asumsi variabel independen yang lain dalam model regresi adalah tetap.

Variabel NPL (X2) terhadap Penyaluran Kredit UMKM (Y) mempunyai nilai koefisien positif sebesar 0.284 ini berarti setiap kenaikan nilai variabel NPL sebesar 1 persen maka nilai variabel UMKM akan bertambah sebesar 0.284 persen dengan asumsi variabel independen yang lain dalam regresi adalah tetap. Variabel Retrun Of Asets ROA (X3) berpengaruh positif terhadap variabel penyaluran kredit UMKM (Y) mempunyai niali koefisien sebesar 0.105 ini berarti setiap kenaikan variabel ROA naik sebesar 1 persen maka nilai variabel penyaluran kredit UMKM akan bertambah sebesar 0.105 persen dengan asumsi variabel independen yang lain dalam model regresi adalah tetap.

\section{Hasil Pengujian Koefisien Determinasi $\left(\mathbf{R}^{2}\right)$}

Untuk melihat pengaruh factor-faktor independen yang di gunakan dalam penelitian ini yakini, variaebel CAR (X1), NPL (X2) dan ROA (X3) terhadap penyaluran kredit UMKM (Y) secara gabungan, dapat lihat dari hasil perhitungan dalam model summary , khususnya angka R sguare pada tabel di atas sebagai berikut.

Hasil Uji Koefisien Determinasi $\left(\mathbf{R}^{2}\right)$

\begin{tabular}{|c|c|c|c|c|}
\hline \multicolumn{5}{|c|}{ Model Summary } \\
\hline Model & $\mathbf{R}$ & R Square & Adjusted R Square & $\begin{array}{c}\text { Std. Error of the } \\
\text { Estimate }\end{array}$ \\
\hline 1 & $.995^{\mathrm{a}}$ & .991 & .963 & 8587.266 \\
\hline \multicolumn{4}{|l}{ a. Predictors: (Constant), ROA, NPL, CAR } \\
\hline
\end{tabular}

Hasil pengolahan SPSS diperoleh besarnya R sguare $\left(r^{2}\right)$ adalah sebesar 0,991 . Angka tersebut dapat digunakan untuk melihat besanya pengaruh ke tiga variabel bebas, CAR, NPL dan ROA terhadap penyaluran kredit UMKM dengan cara menghitung Koefisien Determinasi (KD) dengan mengunakan rumus sebagai berikut: 
$K D=r^{2} \times 100 \%$

$K D=0,992 \times 100 \%$

$K D=99,2 \%$

Angka tersebut mempunyai maksud bahwa pengaruh ketiga variabel bebas yang digunakan dalam penelitian ini, secara gabungan berpengaruh terhadap penyaluran kredit UMKM di Bank Pembangunan Daerah Maluku, Malut adalah 99,\%. Adapun sisanya sebesar 09,0\% dipengharuhi oleh faktor lain. Dengan kata lain, variabel CAR, NPL dan ROA adalah sebesar 99,1\%, sedangangkan 09,0\% disebabkan oleh variabel-variabel lain di luar model ini.

\section{Penutup}

\section{Simpulan}

Berdasarkan pembahasan hasil temuan penelitian ini maka yang menjadi simpulan adalah sebagai berikut;

1. Berdasarkan hasil uji model hubungan faktor-faktor yang mempengharuhi penyaluran kredit UMKM di Bank Pembangunan Daerah Maluku, Malut. Peranan penyaluran kredit UMKM oleh perbankan dalam hal ini Bank Pembangunan Daerah Maluku, Malut sangat berpengaruh akan meningkatkan pertumbuhan ekonomi dan akan meningkatkan investasi yang mengakibatkan peningkatan produksi dan dengan sendirinya akan meningkatkan pendapatan, peningkatan pendapatan akan meningkatkan tingkat pertumbuhan ekonomi serta kesejahteraan masayarakat yang pada gilirannya akan meningkatkan pertumbuhan ekonomi daerah.

2. Pertumbuhan penyaluran kredit UMKM secara umum kecukupan modal bank yang diproksikan dengan CAR, NPL, dan ROA memiliki pengaruh positif dan signifikan terhadap jumlah penyaluran kredit UMKM. Hal ini dibuktikan dengan tingkat signifikan CAR, NPL dan ROA yang lebih kecil dari 0,05 sehingga Dari hasil pengolahan diperoleh besarnya R sguare ( $\left.r^{2}\right)$ adalah sebesar 0,991. Angka tersebut mempunyai maksud bahwa pengaruh ketiga variabel bebas yang digunakan dalam penelitian ini, secara gabungan berpengaruh terhadap penyaluran kredit UMKM di Bank Pembangunan Daerah Maluku, Malut adalah 99,1\%. Adapun sisanya sebesar 09,0\% dipengharuhi oleh faktor lain. 
3. Besaran koefisien pada masing-masing variabel independen menunjukkan besarnya pengaruh masing-masing variabel terhadap variabel independen. Variabel CAR (X1) memiliki koefisien sebesar 0,043 yang berarti apabila penyaluran kredit UMKM meningkat sebesar $1 \%$, maka Penyaluran kredit dari variabel CAR (X1) akan meningkat sebesar $0,043 \%$; variabel NPL (X2) memiliki besaran koefisien sebesar 0.284 yang berarti apabila penyaluran kredit UMKM meningkat sebesar 1\%, maka vaktor variabel NPL akan meningkat sebesar $0.284 \%$. Demikian halnya dengan besaran koefisien variabel ROA (X3) sebesar 0.105 yang berarti apabila penyaluran kredit UMKM meningkat sebesar $1 \%$ maka vaktor variabel ROA daerah akan meningkatkan sebesar $0.105 \%$.

\section{Saran}

Berdasarkan simpulan hasil temuan penelitian ini maka yang menjadi saran adalah sebagai berikut;

1. PT. Bank Maluku Malut perlu mengatur seluruh alokasi asetnya dan jumlah pengembalian atas aset diperoleh secara maksimal, sehingga dana yang didapat dari pengembalian atas aset tersebut dapat disalurkan kepada kredit UMKM yang akan disalurkan oleh bank.

2. Demikian juga PT. Bank Maluku Malut harus melihat jumlah volume kredit yang disalurkan oleh bank kepada debitur perlu memperhatikan faktor internal dan faktor eksternal yaitu kemampuan bank dalam menghimpun dana masyarakat dan penentuan tingkat suku bunga.

3. Bagi peneliti selanjutnya, sebaiknya dapat menambah variabel lainnya diluar variabel dalam penelitian ini karena masih banyak terdapat variabel-variabel independen lainnya, dan juga model dan alat analisis.

\section{Implikasi Hasil Penelitian}

Bersadarkan hasil penelitian dan kesimpulan maka diajukan beberapa saran serta implikasi kebijakan yang dapat diterapkan perbankan guna penetuan kebijakan bagi perusahaan perbankan khususnya mengenai keputusan penyaluran kredit UMKM, yakni; hasil penelitian menunjukkan bahwa pengaruh ketiga variabel bebas yang digunakan dalam penelitian ini, secara gabungan berpengaruh terhadap penyaluran kredit UMKM di Bank Pembangunan Daerah Maluku, Malut adalah 99,1\%. Adapun sisanya sebesar 09,0\% 
dipengharuhi oleh faktor lain. Dan besaran koefisien pada masing-masing variabel independen menunjukkan besarnya pengaruh masing-masing variabel terhadap variabel independen.

4. Oleh karena itu, bank perlu mengatur seluruh alokasi asetnya dan jumlah pengembalian atas aset diperoleh secara maksimal. Sehingga dana yang didapat dari pengembalian atas aset tersebut dapat disalurkan kepada kredit UMKM yang akan disalurkan oleh bank.

5. Demikian juga bank harus melihat jumlah volume kredit yang disalurkan oleh bank kepada debitur perlu memperhatikan faktor internal dan faktor eksternal yaitu kemampuan bank dalam menghimpun dana masyarakat dan penentuan tingkat suku bunga.

6. Saran bagi peneliti yang akan meneliti masalah yang sama sebaiknya dapat menambah variabel lainnya diluar variabel dalam penelitian ini karena masih banyak terdapat variabel-variabel independen lainnya, dan juga model dan alat analisis.

\section{Daftar Pustaka}

Annisa Nurlestari, M. K. M. (2015). Analisisfaktor-Faktor Yang Mempengaruhipenyaluran Kredit UMKM (Studi Pada Bank Umum yangTerdaftar di Bursa Efek Indonesia Periode 2009-2013). Jurnal Manajemen, 4,Nomor4, 1-12. http://ejournals1.undip.ac.id/index.php/dbr

Barus, A. C. (2016). Analisis Faktor-Faktor Yang Mempengaruhi Non Performing Loan Pada Bank Umum Di Indonesia. Jurnal Ekonomi \& Bisnis, 6, Nomor 0.

Fitria. (2012). Analisis Kebijakan Pemberian Kredit dan Pengaruh NPL Terhadap Loan To Deposit Ratio Pada PT Bank Rakyat Indonesia (Persero), Tbk Cabang Rantau, Ace Tamiang (Priode 2007-2011). Jurnal Ekonomi Dan Keuangan, 1 No.1.

Ghozali, I. (2011). Aplikasi Analisis Multivariate dengan Program SPSS. Semarang: Universitas Diponegoro.

Huda, G. F. (2014). Pengaruh DPK, CAR, NPL DAN ROA Terhadap Penyaluran Kredit(Studi Pada BankUmum Yang Terdaftar Di Bursa Efek IndonesiaPeriode2009-2012). Jurnal Ekonomi \& Bisnis.

Kusnandar, E. (2012). Analisis Faktor-faktor yang mempengaruhi Pemberian Kredit UMKM 
oleh Perbankan di Indonesia. Tesis Pascasarjana Universitas Indonesia, Jakarta. Jurnal Akuntansi \& Keuangan.

Mahendra, A. (2011). Pengaruh Kinerja Keuangan terhadap Nilai Perusahaan (kebijakan

Dividen Sebagai Variabel Moderating) Pada Perusahaan Manufaktur di BEI Universitas Udayana. Jurnal Ekonomi \& Bisnis.

Meyddinawathi, L. G. (2007). Analisis Perilaku Penawaran Kredit Perbankan Kepada Sektor

UMKM di Indonesia, Fakultas Ekonomi, Universitas Udayana, Bali. Jurnal Ekonomi \& Bisnis.

Nasution, A. dan. (2013). peranan Kredit Usaha Rakyat (KUR) Bagi Pengembangan UMKM di Kota Medan (Studi Kasus Pada Bank BRI). Jurnal Ekonomi dan Keuangan Volume I.No.3. Jurnal Ekonomi Dan Keuangan, 1 No 3.

Panggalih. (2015). Analisis Pengaruh Dana Pihak Ketiga (DPK), Non-Performing Loan(NPL), SukuBunga Sertifikat Bank Indonesia (SBI), dan Suku Bunga KUR Terhadap Penyaluran KreditUsaha Rakyat (KUR) (Studi Pada PT. Bank Rakyat Indonesia (Persero) Tbk. PeriodeJanuari 2012-Agustu. Jurnal Ekonomi \& Bisnis.

Pratama, B. A. (2010). Analisis Faktor-Faktor Yang Mempengaruhi Kebijakan Penyaluran Kredit Perbankan ( Studi Pada Bank Umum di Indonesia Periode tahun 2005-2009) Semarang: Universitas Dipenogoro. Jurnal Akuntansi \& Keuangan, 397-403.

Siregar, F. dan D. H. S. (2009). Pengaruh Faktor Internal Bank Terhadap Volume Kredit Pada Bank Yang Go Public Di Indonesia". Jurnal Akuntansi 6. Sumatera Utara. Diakses tanggal 10 November 2010. Jurnal Akuntansi. http://akuntansi.usu.ac.id/jurnalakuntansi-6.html

Triasdini, H. (2010). Pengaruh CAR, NPL, dan ROA terhadap penyaluran kredit modal kerja. Skripsi. Dipublikasikan. Semarang: Universitas Diponegoro. Jurnal Akuntansi \& Keuangan.

Trimulyanti, I. (2013). Analisis Faktor-Faktor Internal Terhadap Pertumbuhan Penyaluran Kredit (Studi Pada Bank Perkreditan Rakyat Kota Semarang Periode 2009-2012)". Jurnal Fakultas Ekonomi Dan Bisnis Universitas Dian Nuswantoro 2013.

Tuah, A. (2007). Analisis Pengaruh Spread Tingkat suku bunga perbankan, SBI, Dana Pihak Ketiga, dan Kebijakan Alokasi KUK terhadap penyaluran KUK oleh Perbankan. Skripsi. Jurnal Ekonomi \& Bisnis. 
Wardhani, S. (2011). Analisis Pengaruh Spread Tingkat Suku Bunga Bank, CAR, dan NPLTerhadap Penyaluran Kredit UMKM Oleh Perbankan di Indonesia.Skripsi. Program S-1Ilmu Ekonomika dan Bisnis Universitas Diponegoro. Jurnal Ekonomi \& Bisnis. 